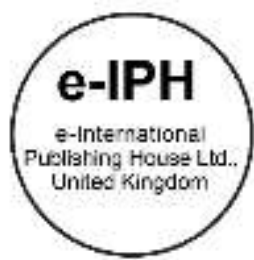

\title{
Law Enforcement Issues during Covid-19: Experience from Malaysia and Indonesia
}

\author{
Habibah Omar ${ }^{1}$, Indrawati S.H. ${ }^{2}$, Che Audah Hassan ${ }^{1}$ \\ ${ }^{1}$ Faculty of Law, Universiti Teknologi MARA, Malaysia \\ ${ }^{2}$ Faculty of Law, Airlangga University, Indonesia \\ habib597@uitm.edu.my; indrawati@fh.unair.ac.id; audah@uitm.edu.my \\ Tel : 019-2792145
}

\begin{abstract}
This article examines the legal issues relating to the State Administrators' enforcement of policies, rules, and decision-making in Malaysia and Indonesia during the pandemic from the perspective of administrative law. The State Administrators have come out with various Standard Operating Procedures (SOP) that impacted the people. It is argued that administrative law can discern potential abuse by State administrators while enforcing the law. This article will examine the enforcement issues in both nations by utilizing doctrinal and comparative analysis. Consequently, some exercise of discretion of the executive can be questioned and challenged under the purview of administrative law.
\end{abstract}

Keywords: Administrative law, law enforcement, administrative discretion; Covid-19

eISSN: 2398-4287 @ 2020. The Authors. Published for AMER ABRA cE-Bs by e-International Publishing House, Ltd., UK. This is an open access article under the CC BYNC-ND license (http://creativecommons.org/licenses/by-nc-nd/4.0). Peer-review under responsibility of AMER (Association of Malaysian Environment-Behaviour Researchers), ABRA (Association of Behavioural Researchers on Asians) and cE-Bs (Centre for Environment-Behaviour Studies), Faculty of Architecture, Planning \& Surveying, Universiti Teknologi MARA, Malaysia.

DOI: https://doi.org/10.21834/ebpj.v6iSl6.3052

\subsection{Introduction}

The Covid-19 pandemic has driven people worldwide to adapt to new norms to contain its reach. The pandemic has resulted in State administrations becoming more testing. The task of enforcing pandemic-related measures by law enforcers becomes tougher. The emerging trend is that individuals' rights are set aside in the name of public health. The State is increasingly leaning towards an authoritarian regime by implementing interventionist policies with a highly centralized decision-making process and aggressive law enforcement. This is the current global trend. The same modus operandi is seen in Malaysia and Indonesia to contain the pandemic, albeit with some divergence. Thus, this paper aims to analyze the extent of the exercise of power and discretion regarding the enforcement of the policies and rules by State administrators in Malaysia and Indonesia. Effective control measures under administrative law need to be revived as a check and balance on state administration's exercise of discretion. By way of doctrinal analysis and comparative study, this paper will examine how administrative law is being utilized to control state administrators and law enforcers from committing abuse of powers. This paper will look at the experience from Malaysia and Indonesia to see if the measures under administrative law are functioning well during this pandemic's trying times.

\subsection{Literature Review}

The state administrators perform an essential task in coping with the pandemic. The complexity and grave force of Covid-19 necessitate immediate and adaptable effort in addressing health, social and economic difficulties. The parliament is not equipped with this flexibility. Hence, the state administrators are the authority to be relied on (Griglio, 2020).

eISSN: 2398-4287 @ 2020. The Authors. Published for AMER ABRA cE-Bs by e-International Publishing House, Ltd., UK. This is an open access article under the CC BYNC-ND license (http://creativecommons.org/licenses/by-nc-nd/4.0/). Peer-review under responsibility of AMER (Association of Malaysian Environment-Behaviour Researchers), ABRA (Association of Behavioural Researchers on Asians) and cE-Bs (Centre for Environment-Behaviour Studies), Faculty of Architecture, Planning \& Surveying, Universiti Teknologi MARA, Malaysia.

DOI: https://doi.org/10.21834/ebpj.v6iSl6.3052 
State administrators are empowered with rule-making and decision-making authority and must exercise the discretionary powers within boundaries outlined by law. Administrative law attempts to structure and define the permissible limits of the State's exercise of discretionary activities.

Power corrupts; absolute power corrupts absolutely (Acton, 1887). One of the controls of the exercise of administrative actions is by having an effective system of check and balance offered by the doctrine of separation of powers (Montesquieu, 1748). The three organs of government, i.e., the executive, legislative, and judiciary, must exercise their powers independently. Each check and balances each other's exercise of powers. Administrative law is an established mechanism of control of the exercise of discretion of the state administrators and decision-making through judicial review. For example, in the United Kingdom, many cases have been brought to court for judicial review as many of the policies and laws made to control the pandemic encroached on human rights (Ganz, 2020). This law is also a part of the law in Malaysia as enshrined in the Federal Constitution (Omar, Mansoor, Ramli, \& Mohammad Salleh, 2020). In Indonesia, based on the principle of legality, every administrative act must be based on law, either in law-making by state administration or in the aspects of law enforcement (Husni, Syahbandir, Kadir, \& Dadek, 2021). Unfortunately, many health protocols utilized in the control of Covid-19 are in the form of minister's health regulation which is not within the realm of a positive law of the Indonesian legal system; hence it may be questioned.

Indeed, the pressure of Covid-19 is felt by people and law enforcers (Farmer \& Copenhaver, 2021). Policing violations in light of vague and inconsistent policies intensified this strain (Papazoglou, Blumberg, Schlosser, \& Collins, 2020) (Stogner, Miller, \& McLean, 2020). Dissatisfaction with the legitimacy of the rules (for example, emergency proclamation or random policy making) and eventually enforcement of these rules undermines public trust and give rise to people questioning the rules, actions, and decisions (Jones, 2020) (Laufs \& Waseem, 2020). State administrators and law enforcers use vast discretion. The pandemic has driven nations worldwide to initiate and assume measures that inhibit civil liberties while intensifying the powers of law enforcers (White \& Fradella, 2020) (Stott, West, \& Harrison, 2020). Responsible state administrators must be accountable for their actions (Boughey, 2020).

The attempt to control the pandemic has led to a more authoritarian approach to governance (Thomson \& Ip, 2020). ICNL.org reported that a total of 107 of 192 countries in the world had declared a State of emergency (INCL, 2021). Despite this, governments' obligations to uphold fundamental rights and liberties should remain even in the State of health emergency and, as such, must be viewed seriously once imposed on individuals (Henry, 2019). The skirmish is always between the rights and individual freedom to choose, survive, and live with that of the collective interest under the banner of public health. Public health and public good argument are becoming increasingly dominant in every policy, decision making, and action by state administrators and law enforcers.

The UN of Human Rights has made a statement relating to the trend of declaring an emergency by states. The authority has published a guideline on how emergency is to be treated (UN, 2020). Declaration of emergency shall make it lawful to halt and take away rights, but such measures should be averted if they can be satisfactorily dealt with by ordinary legislation. The intrusion of rights must be proportionate and in limited and necessary situations.

According to Thomson and Ip (2020), authoritarian governance is where the government and state administrators exercise their powers and discretion beyond normal boundaries depicted by the law by invoking, for example, emergency measures that are unwarranted and excessive. Frequent encroachment and disregard of rights and fundamental freedom, engaging in the ambiguous and highly centralized decision-making process in total disregard to public participation while eliminating legal and democratic control (Griglio, 2020). Public health and national interest became the motto to justify authoritarianism denying human autonomy, privacy, and fundamental rights. The constant clash between collective interests and individual rights subsists. Exercise of administrative or executive powers must function within the limit allowed. Exercise of powers outside the ordinary structures of checks and balances should only be warranted if the harm cannot be customarily neutralized. (Haajee, Parmet, \& Mello, 2014). As such, an emergency declaration due to Covid-19 should not be used as an instrument to enhance political powers (Petrov, 2020). The pandemic has created a new phenomenon on governance; intending to protect public health, it makes democracy sick (Croissant, 2021)(Grace, 2021).

\subsection{Methodology}

This paper is socio-legal research that was designed based on primary and secondary data. The aspects of law enforcement during Covid-19 by law enforcers in Malaysia and Indonesia reflect the exercise of discretion that may exceed the purview allowed by the law. The discussion in this paper is limited to looking at the rules and such enforcement aspects via comparative, doctrinal analysis and theoretical discourse. An analysis is made on the approaches of law enforcement in Malaysia and Indonesia and to examine whether administrative law can provide for mechanisms of control against abuse of power in law enforcement. The data is reviewed via a content analysis approach and doctrinal study.

\subsection{Finding and Discussion}

In the desire to control the spread of the pandemic, governments of both Malaysia and Indonesia have resorted to measures that may be detrimental to the idea of democracy and fundamental liberties. Questionable actions and decisions that may fall within the ambit of abuse of powers and discretion can be perceived in both countries' day-to-day running of enforcement activities in the name of containment of the Covid-19 pandemic. 


\subsection{Covid-19 Proclamation of emergency}

Proclamation of emergency is a measure taken by many countries in the mission to contain the spread of the virus. The same measure was also taken by the Malaysian government for the containment of the virus. There were allegations that this was only a mechanism for the government to stay in power as to stunt the political threat for a snap election. The power under the Prevention and Control of Infectious Disease Act 1988 was claimed to be wide enough that made the emergency call unnecessary.

Indeed, Malaysia was in a state of emergency upon a declaration made by the Yang di-Pertuan Agong (YDPA) on 11 March 2021, which ended on 1 August 2021. Such declaration was indeed allowed by article 150 of the Federal Constitution. The YDPA acted on the prime minister's advice. However, the legitimacy of this proclamation was questioned since when the YDPA made the proclamation, political turmoil was embroiling the country. This raises the question of whether such declaration was indeed genuine and needed. The emergency declaration stunted the call for a general election. More importantly, no sitting of Parliament and State Legislative Assembly was allowed making every policy, law, and actions of the executive exempted from being scrutinized, debated, or reviewed. As such, decisions and actions of the government relating to the SOPs such as the quarantine rules, travelling and business rules and many other that impacted the people were not debated and scrutinized. The Ordinances that were passed by the executives were also not examined. Such government actions weaken institutional checks on their rule via an emergency declaration, and the people responded with compliance (Thomson \& Ip, 2020).

Such proclamation has led to several actions filed in the High Court for judicial review to question the validity of the declaration of emergency, the Prime Minister's advice to the YDPA, especially concerning the order for the suspension of parliament. The applications, however, were rejected when the courts declared that the executive's decision was not justiciable. In this context, the court could not lend protection to the rule of law via judicial review.

Another issue that caused concern was when the law minister announced the revocation of the proclamation of emergency prematurely upon a decision made in a Cabinet meeting. This raised a constitutional question on how the minister handled such an issue. It has gone against the constitutional provision where the annulment of an emergency declaration is to be made by the parliament upon passing a resolution. The government of the day was deemed to have turned its back to the authority of the YDPA as the Head of the country. These incidents reflect perhaps a high and mighty approach of the State in decision making when governing the State, a sign of erosion of democracy and the rule of law.

Indonesia also utilized the emergency law. Article 12 of the Indonesian Constitution empowers the President to declare, and he declared a health emergency in March 2020 based on Law No. 6 of 2018 on Health Quarantine. The State administrators have also utilized President Decree No.11 Year 2020 regarding the Determination of Public Health Emergency Corona Virus Disease (Covid-19) (PRI, 2020); Government Regulation No.21 Year 2020 regarding Large Scale Social Distancing in order to Accelerate the Handling of Covid-19 (GR Social Distancing) (GRI, 2020); Government Regulation in lieu of Law No.1 Year 2020 regarding State Financial Policy and Financial System Stability to Handle Covid-19 (RI, 2020). Such emergency declaration has led to the passing of laws in relation to finance and government spending that was regarded as dubious by civil societies. On top of this, other regulations issued the Minister of Health Regulation No.9 Year 2020 regarding Guidance for Large Scale Social Distancing in order to Accelerate the Handling of Covid19) (MoH Guidance) (Widjaja, 2020) was also inconsistent in terms of its application and enforcement. The different levels and hierarchies in which the of law applied and enforced reflects some issues of concern.

Like Malaysia, some civil societies in Indonesia are also taking actions against the government for judicial review at the Constitutional Court for the law passed. For example, the regulation passed in lieu of law (Perppu) gives state administrators excessive power. It was also reported that the court's registrar had recorded more than 70 applications for judicial review (as of March 2020) at the Constitutional Court questioning the enactment of various laws since the pandemic (Adhani, 2020). This reflects concerns of the people on the law passed by the State.

\subsection{Regulations and Penalties under the Law: Challenges in the implementation of the rules}

In Malaysia, the proclamation of emergency empowered the executives to make laws in the form of emergency ordinances. Hence, the Emergency (Essential Powers) Ordinance 2021 and Emergency (Essential Powers) (No 2) Ordinance 2021 are passed. These laws are passed without approval by the parliament. The Emergency (Essential Powers) (No 2) Ordinance 2021 revived the repealed draconian Anti-Fake News Act 2018, which infringed on the freedom of speech. Such regulation was alleged to instill fear in those who dared to criticize the government. Not only that the offense is vaguely worded, but the punishment is also severely increased (Bernama, 2021). People have been charged upon the allegation of spreading fake news relating to Covid-19. This has resulted in a challenge made at the High Court on the validity of the Ordinance, the decision of which is still pending.

The counterpart in Indonesia has various policies and laws in place but came upon issues of lack of clarity and poor implementation. The increasing cases of Covid-19 infection in Indonesia were contributed by the Indonesian government's slow response and unclear policy, leading to weak enforcement (Husni, Syahbandir, Kadir, \& Dadek, 2021). Public Officials even made statements that Indonesia was free from Covid-19 when the virus was believed to have been there since February 2020 (Roziqin, Mas'udi, \& Sihidi, 2021).

The health emergency status suffered drawbacks and severe criticisms when the State implemented a large-scale social restriction that allowed social activities involving economic and religious gatherings. This non-lockdown policy allowed people to travel to other Indonesian regions. The control of people's mobility was poorly enforced. Incidents of people flocking the transportation hub to return to their villages for Eid and people, in droves, celebrating the return of a liberation leader increased the spread by close contact. The implementation of Government Regulation Social Distancing unsupported with other comprehensive regulations and holistic implementation did not bring an effective outcome (Widjaja, 2020). In terms of quarantine rules, Indonesia has various categories of 
quarantine put into operation depending on different levels of governance. This has led to misregulations (Widjaja, 2020) and a lack of coordination between national and regional governments on the rules to be applied (Sulistiawati, 2020).

Inconsistency in the exercise of discretion by state administrators and law enforcement officials has also caused dissatisfaction among public members. For example, a double standard in implementing SOPs, the 14-days quarantine rules, or exceeding business operation hours saw ordinary individuals being excessively fined and imprisoned (The Sundaily, 2021). A massive increase of penalty under the emergency law, and the fact that enforcement officers have imposed the maximum penalty, has caused uproars and criticism among the public due to the disproportionate nature of the offense and the sanction (The Malay Mail, 2021).

Political benefit saw the SOP for quarantine being waived to make possible inter-states travels and campaign activities during the Sabah by-election. Sabah was at that time already suffering from the spiking number of Covid-19 cases. Even though the Election Commission has come out with a comprehensive procedure for election, it was not able to curtail the spread of the virus. The government has detected various clusters linked with the Sabah election, which has led Malaysia into the third wave of the pandemic attack (Zainudin, Kassim, \& Ridza, 2020).

In both instances, the government was severely criticized for its irrational decision-making and unreasonable law implementation and enforcement. They clearly went against the principles of administrative law.

Another issue that raises concern is with regards to the vaccine. Information or misinformation about vaccine or vaccine hesitancy has been in existence long before the Covid-19 pandemic (Nahum, Drekonja, \& Alpern, 2021). The issue would be whether vaccination should be made mandatory. The policy decision to make Covid-19 vaccination mandatory interferes with individual liberty and autonomy, reflecting a sign of erosion of democracy and respect for human rights. Mandatory vaccination is regarded as a form of inequity or oppression. Some nations, however, have made vaccination against Covid-19 mandatory (Wang, Moribe, \& Arruda, 2021).

When dealing with vaccination issues, the two central conflicting claims will always be between the need for the State to achieve herd immunity for the preservation of life and health, as opposed to the right of an individual to choose; the autonomy over one's own body. Mandatory vaccination should not be employed unless all other measures have been exhausted. The government should not use mandatory vaccination to satiate the inefficiency of the state administrators in policy formulation and implementation and, indeed, not be regarded as the policy to be invoked in the control of the pandemic (Kheng \& Hasbullah, 2020).

Covid-19 vaccination is not made mandatory by the Malaysian government (Jun, 2021). The government, however, encourages mandatory Covid-19 vaccinations on a sectoral basis (Thomas, 2021). Under Malaysia's National Covid-19 Immunisation Programme (PICK), Covid-19 vaccination is administered voluntarily. It will be provided free of charge to all residents in Malaysia (citizens and noncitizens) aged 18 years old and above. However, some Malaysians opt to refuse a vaccine for various reasons, among others, the sideeffects, efficacy, and safety of the vaccine (Covid-19 vaccines were approved in a short period and have never been tested, hence, raises concern of its safety), personal beliefs and conspiracy theory (Tan, 2021) (Ganz, 2020) (Nahum, Drekonja, \& Alpern, 2021). To date, only one Covid-19 vaccine is approved by the US Food and Drug Administration (FDA), while the rest were authorized to be used via emergency use authorization (EUA) (FDA, 2021). This shows that some aspects of research and clinical trials may not have been fully completed causing a statistically high number of Americans refused to be vaccinated (James G. Hodge, et al., 2021). This perhaps justifies Biden's administration's relaxed approach to vaccination.

Malaysian aimed to have $80 \%$ of its population vaccinated to achieve herd immunity by February 2022 (The Sundaily, 2021). Research concluded that with the vaccine of $95 \%$ efficacy, $78 \%$ of the Malaysian population needs to be vaccinated (Ganasegeran, Ch'ng, \& Looi, 2021). However, there have been reports of Malaysians refusing vaccines (Camoens, 2021). In the mission of reopening the economy by state administrators, the government has recently moved to relax the SOPs, allowing various social activities. This has led to the vaccination issues appearing at the center stage.

There is no legislation expressly mandating mandatory vaccination in Malaysia. However, there have been cases where state administrators have placed pressure on those who refused to be vaccinated contrary to the pledge that it is not mandatory (The Star, 2021) (Parkaran, 2021). This has resulted in many police reports made against state administrators, which may become the starting point for judicial review action in the future.

Indonesia makes vaccination compulsory to its people, presumably in line with the spirit of the Indonesian Constitution as per the Preamble to the 1945 Constitution. Refusing vaccination is against the law. In the effort to enforce mandatory vaccination, the government has resorted to administrative law that imposes criminal sanctions to vaccine violators. If an individual refuses to be vaccinated and is criminally sanctioned, he can be subsequently forced to be vaccinated again at a later time. This creates a very awkward situation when the individual can be penalized again and again. The disparity of the law and implementation between regions also amplified the problem (Bustomi, 2021). This has resulted in some individuals making applications for judicial review to the Supreme Court concerning the rules for fine sanctions for vaccine violators (Wijayanti, 2021).

\subsection{Conclusion and Recommendation}

Covid-19 has changed the way people behave and modified the executive's style of governing. In most parts of the world, the rule of law and separation of powers are gradually eroded in the name of public health. Administrative rulemaking and decision-making are regarded as exclusive rights of the executive, to be utilized according to their wish and interest. Nevertheless, administrative law continues to be the tool in controlling the exercise of administrative discretion and law enforcement. However, an independent and robust judiciary is paramount in checks on executive actions (Thomson \& Ip, 2020) (Grace, 2021).

Thus far, the executives, i.e., the state administrators and law enforcers, can fend themselves upon the claim of judicial review on the basis that administrative law recognizes the exercise of executive's discretion so long it is not illegal nor irrational and if the 136 
encroachment is justified and proportionate with the end of achieving health. The court, however, must remain objective in balancing conflicting claims to ensure that the rule of law is preserved, and human rights respected.

In the context of Malaysia, on matters relating to declaration of emergency, the court has taken a rather restrictive approach by interpreting the provisions of the law literally and abstain from encroaching on matters which they regard as non-justiciable. On the other aspects of the law and enforcement, we are still awaiting how the court resolves the conflict and whether administrative law lends protection against potential abuse. In addition, time, together with economic constraints, becomes the unrelenting factor in influencing whether an action will be brought to court by the injured party during this trying time of the pandemic. And if such actions are taken, whether our court is robust enough to view the conflicting claims based on rule of law. The decisions of the court will not always be immediate. This has become the main stumbling block in resorting to the court in actions for judicial review.

In the meantime, the public and civil societies have no alternative but to take advantage of the technology. The time spent locked at home and observed was used to scrutinize the actions of the law enforcers and administrative decision-makers. Social media has become the platform to check and balance the state administrations' and law enforcers' discretion.

Similarly, in Indonesia, the public has also utilized social media to express their aspirations and dissatisfaction to ensure democracy, human rights, and the principle of legality are observed. It is hoped that the rule of law, democracy, and respect will be part of the principles that the State follows in the desire to maintain public health during the pandemic.

\section{Acknowledgements}

This research receives no external funding.

\section{References}

Acton, L. (1887, April 3). British historian: letter to Bishop Mandell Creighton.

Adhani, H. (2020). Constitutional Court Of The Republic Of Indonesia: Safeguarding Citizens' Constitutional Rights In The Middle Of A Pandemic. INSLA E-Proceedings. 3, pp. 609-615. Insla USIM.

Astro Awani. (2021, June 2). Housewife, tutor first to be charged under Emergency Ordinance. Astro Awani. Kuala Lumpur: Bernama.Boughey, J. (2020). Executive power in emergencies: Where is the accountability?. Alternative Law Journal, 45(3), 168-174 (https://doi.org/10.1177/1037969X20950514)

Bernama. (2021, february 26). RM10,000 fine for SOP violations beginning March 11. New Straits Times. Kuala Lumpur: New Straits Times Press.

Bustomi, Y. (2021). Conflict Between Health Law and Territorial Quarantine Law Regarding the Provision of Covid-19 Vaccine. . Unnes Law Journal: Jurnal Hukum Universitas Negeri Semarang, 7(1), 153-166. https://doi.org/10.15294/ulj.v7i1.44376.

Croissant, A. (2021). Democracies with Preexisting Conditions and the Coronavirus in the Indo-Pacific Region. The ASAN FORUM (http://www.theasanforum.org/).

Camoens, A. (2021, September 15). Action to be taken against 2,500 teachers who refused Covid-19 vaccines. Kuala Lumpur: The Star Newspaper.

Farmer, A., \& Copenhaver, A. (2021, April 29). Policing in a pandemic: how law enforcement communicates with the public. Policing: An International Journal, https://doi.org/10.1108/PIJPSM-10-2020-0162.

FDA. (2021, August 23). FDA Approves First Covid-19 Vaccine Approval Signifies Key Achievement for Public Health. Retrieved September 2021, from FDA: https://www.fda.gov/news-events/press-announcements/fda-approves-first-covid-19-vaccine

Ganasegeran, K., Ch'ng, A., \& Looi, I. (2021). What Is the Estimated Covid-19 Reproduction Number and the Proportion of the Population That Needs to Be Immunized to Achieve Herd Immunity in Malaysia? A Mathematical Epidemiology Synthesis. COVID 2021, 1(1), 13-19 (https://doi.org/10.3390/covid1010003).

Ganz, D. J. (2020). Reconsidering Discretion In Expedited Vaccine Approval In Light Of The Novel Coronavirus. University Of Illinois Law Review Online, 203-220.

Grace, J. (2021). UK human rights challenges in the time of Covid-19. Ius Publicum Network Review, 1. lus Publicum Network Review, 1-17.

Griglio, E. (2020). Parliamentary oversight under the Covid-19 emergency: striving against executive dominance. The Theory and Practice of Legislation, 8(1-2), 49-70 (DOI: 10.1080/20508840.2020.1789935).

Haajee, R., Parmet, W., \& Mello, M. (2014). What Is a Public Health "Emergency"? New England Journal of Medicine, 371, 986-988.

Henry, L. (2019). An Overview of Public Health Ethics in Emergency Preparedness and Response. In A. Mastrolianni, J. Kahn, \& N. Kass, The Oxford Handbook of Public Health Ethics. New York: Oxford University Press.

Husni, Syahbandir, M., Kadir, M. Y., \& Dadek, T. A. (2021, January-March). Legal Constraints on the Enforcement of Covid-19 Healyh Protocol in Indonesia. Medico-legal Update, 21(1), 1601-1611.

INCL. (2021). Retrieved June 2021, from International Centre Not-for-profit Law: https://www.icnl.org/covid19tracker/?issue=5

James G. Hodge, J., Piatt, J. L., Barraza, L., Freed, R., Ghaith, S., \& Wells, N. (2021). Legal Challenges Underlying Covid-19 Vaccinations. Journal Of Law, Medicine, \& Ethics: Public Health and The Law. 
Jones, D. (2020). The potential impacts of pandemic policing on police legitimacy: planning past the Covid-19 crisis. Policing: A Journal of Policy and Practice, 14(3), 579586

Jun, S. W. (2021, January 5). Khairy: Covid-19 vaccine won't be mandatory. Kuala Lumpur: The Malay Mail.

Kheng, K. S., \& Hasbullah, N. E. (2020). Should Covid-19 Vaccines Be Mandatory? Institute of Strategic and International Studies. Institute of Strategic and International Studies. Retrieved from https://www.jstor.org/stable/resrep29705

Laufs, J., \& Waseem, Z. (2020). Policing in pandemics: a systematic review and best practices for police response to Covid-19. International Journal of Disaster Risk Reduction, 51, 101812.

Manzano, M. P., Sánchez, J. A., \& Rosique, M. M. (2017). Multilevel Protection of the Principle of Legality in Criminal Law. Montesquieu. (1748). De l'esprit des lois (The Spirit of Laws).

Nahum, A., Drekonja, D. M., \& Alpern, J. D. (2021). The Erosion of Public Trust and SARS-CoV-2 Vaccines: More Action Is Needed Open Forum Infectious Diseases PERSPECTIVES . Open Forum Infectious Diseases Perspectives . Oxford.

Omar, H., Mansoor, M., Ramli, L., \& Mohammad Salleh, H. F. (2020). Corruption and Accountability of Public Officials: Comparative analysis from Malaysia and Indonesia. Environment-Behaviour Proceedings Journal, 5(15), 269-274 https://doi.org/10.21834/eb.Papazoglou, K., Blumberg, D. M., Schlosser, M. D., \& Collins, P. I. (2020, July). Policing During Covid-19: Another Day, Another Crisis. Journal of Community Safety and Well-Being, 5(2).

Parkaran, K. (2021, September 6). About-turn on action against soldiers whose spouses shoot down vaccination. Free Malaysia Today.

Petrov, J. (2020). The Covid-19 emergency in the age of executive aggrandizement: what role for legislative and judicial checks? The Theory and Practice of Legislation, 8(1-2), 71-92 (DOI: 10.1080/20508840.2020.1788232).

Roziqin, A., Mas'udi, S. Y., \& Sihidi, I. T. (2021). An analysis of Indonesian government policies against Covid-19. Public Administration and Policy, 24(1), 92-107.

Stogner, J., Miller, B., \& McLean, K. (2020). Police stress, mental health, and resiliency during the Covid-19 pandemic. American Journal of Criminal Justice, pp. 1-13, 10.1007/s12103-020-09548-y.

Stott, C., West, O., \& Harrison, M. (2020). A turning point, securitization, and policing in the context of Covid-19: building a new social contract between state and nation? Policing: A Journal of Policy and Practice, 14(3), 574-578, https://doi.org/10.1093/police/paaa021.

Tan, B. (2021, August 22). In Johor, state govt to counsel 779 teachers who refuse to be vaccinated. The Malay Mail.

The Jakarta Post. (2021, May 27). Rizieq sentenced to eight months in prison for flouting Covid-19 curbs Islam Defenders Front (FPI) leader Rizieq Shihab arrives at The Jakarta Metro Police Headquarter in Jakarta, Saturday, December 12, 2020. Rizieq was summoned by the police after he and. The Jakarta Post. Jakarta.

The Malay Mail. (2021, April 27). After controversy over RM50,000 fine, Takiyuddin say max penalty for exceeding business hours is RM10,000. The Malay Mail.

The Star. (2021, August 23). Soldiers subject to disciplinary action for refusing Covid-19 vaccine, says army. The Star.

The Sundaily. (2021, June 21). Analysis: Challenges Abound but Herd Immunity Still Possible. The Sundaily.

The Sundaily. (2021, 3 12). 330 Individuals fined RM10,000 each for flouting SOP - IGP. The Sundaily. Kuala lumpur.

Thomas, J. (2021, September 9). Ministry nod for mandatory vaccinations by sectors. Kuala Lumpur: Free Malaysia Today.

Thomson, S., \& Ip, E. C. (2020, January-June). Covid-19 emergency measures and the impending authoritarian pandemic. Journal of Law and the Biosciences, 7(1), https://doi.org/10.1093/jlb/lsaa064.

Wang, D. W., Moribe, G., \& Arruda, A. L. (2021, June). Is Mandatory Vaccination for COVID-19 Constitutional under Brazilian Law? Health and Human Rights Journal, 23(1), 163-174.

White, M., \& Fradella, H. (2020). Policing a pandemic: stay-at-home orders and what they mean for the police. American Journal of Criminal Justice, 45, 705-717, doi: $10.1007 / \mathrm{s} 12103-020-09538-0$

Widjaja, G. (2020). Covid-19 Pandemic and Law No. 6 Year 2018 regarding Health Quarantine. Journal of Indonesian Health Policy and Administration, 5(2), $50-56$.

Wijayanti, W. (2021). Anti-Vaccination: Human Right or Public Interest? Proceeding International Conference of Innovation, Science, Technology, Education, Children and Health (ICISTECH). ISBN: 978-623-6089-32-3 https://ahlimediapress.com/prosiding/index.ph.

Zainudin, S., Kassim, M. A., \& Ridza, N. N. (2020). Mitigation Measures during Elections and It's Impacts on Covid-19 Pandemic: Sabah State (Malaysia), New Zealand and the United States. Borneo Epidemology Journal, 1(2), 145-156 